\title{
Field immobilization of raccoons with ketamine hydrochloride and xylazine hydrochloride
}

\author{
Jerrold L. BELANT*
}

\begin{abstract}
Belant J. L. 1995. Field immobilization of raccoons with ketamine hydrochloride and xylazine hydrochloride. Acta Theriologica 40: 327-330.

A 5:1 combination of ketamine hydrochloride $(\mathrm{KH})$ and xylazine hydrochloride $(\mathrm{XH})$ was used to immobilize raccoons Procyon lotor (Linnaeus, 1758). Ten raccoons were intramuscularly injected a total of 11 times with dosages between 22.0 to $38.2 \mathrm{mg} / \mathrm{kg}$ $\mathrm{KH}$ and 4.4 to $7.6 \mathrm{mg} / \mathrm{kg} \mathrm{XH}$. Mean $( \pm \mathrm{SE})$ induction time $(3.4 \pm 0.5 \mathrm{~min})$, recovery time $(101.2 \pm 27.8 \mathrm{~min})$, and resting heart rate $(92 \pm 7.6 \mathrm{bpm})$ was similar to values reported for captive raccoons immobilized with $10 \mathrm{mg} / \mathrm{kg} \mathrm{KH}$ and $2 \mathrm{mg} / \mathrm{kg} \mathrm{XH}$. Mean body temperature decreased $1.3^{\circ} \mathrm{C}$ between 0 and 20 min post-recumbency. Respiration $(23 \pm 4.0)$ was generally deep and consistent. A mixture of $5: 1 \mathrm{KH} / \mathrm{XH}$ is a suitable immobilizing agent for wild raccoons during field studies.

State University of New York, College of Environmental Science and Forestry, Adirondack Ecological Center, Newcomb, New York, 12852, USA
\end{abstract}

Key words: Procyon lotor, ketamine hydrochloride, xylazine hydrochloride, chemical immobilization

\section{Introduction}

Raccoons Procyon lotor (Linnaeus, 1758) have been immobilized with pentobarbital (Mech 1965), chloroform (Moore 1983), phencyclidine (Keeler 1978), phencyclidine plus promazine (Seal and Erickson 1969, Seal et al. 1970), ketamine hydrochloride (KH) (Bigler and Hoff 1974, Gregg and Olson 1975, Ramsden et al. 1976), KH plus acepromazine (Tabatabai 1988, Endres 1989), and KH plus xylazine hydrochloride (XH) (Deresienski and Rupprecht 1989). Seal and Kreeger (1987) recommended $\mathrm{KH}(20 \mathrm{mg} / \mathrm{kg})$ with promazine $(2 \mathrm{mg} / \mathrm{kg})$ or $\mathrm{XH}(1 \mathrm{mg} / \mathrm{kg})$.

$\mathrm{KH}$ with $\mathrm{XH}$ has been used to immobilize many wildlife species. $\mathrm{KH}$, a cyclohexane drug that creates dissociative anesthesia (Aronson 1984), is one of the most commonly used immobilizing agents (Seal and Kreeger 1987). $\mathrm{XH}$ is a nonnarcotic sedative analgesic (Seal and Kreeger 1987) and nonselective $\alpha_{2}$-adrenergic agonist (Docherty and Starke 1981). Transitory hypertension prior to prolonged hypotension is generally induced (Klide et al. 1975, Hsu 1985). KH with $\mathrm{XH}$ usually results in smooth induction and recovery (Harthoorn 1976). I report

\footnotetext{
* Present address: U.S. Department of Agriculture, Denver Wildlife Research Center, 6100 Columbus Avenue, Sandusky, Ohio, 44870, USA
} 
on the use of $\mathrm{KH}-\mathrm{XH}$ for field immobilization of raccoons for research purposes and compare their responses to those of captive raccoons reported by Deresienski and Rupprecht (1989), also immobilized with a 5:1 mixture of $\mathrm{KH} / \mathrm{XH}$.

\section{Material and methods}

Raccoons were captured in $25.4 \times 37.5 \times 81.3 \mathrm{~cm}$ or $38.1 \times 50.8 \times 106.7 \mathrm{~cm}$ wire cage live traps. Meat scraps and/or lure were used as attractants. All raccoons were immobilized via hand-syringe in the wire cage traps at the capture site. Each raccoon was intramuscularly injected in a rear hip with a $5: 1$ combination of $\mathrm{KH}$ and $\mathrm{XH}$. If required, an additional injection of $5-10 \mathrm{mg} / \mathrm{kg} \mathrm{KH}$ and $1-2 \mathrm{mg} / \mathrm{kg}$ $\mathrm{XH}$ was used to maintain anesthesia.

Parameters measured to document raccoon response to immobilization followed Belant (1991, 1992). Induction time was the interval between injection until lateral or sternal recumbency was attained. Arousal time was recorded as the interval between recumbency and upright posturing. Recovery time was defined as the interval between recumbency and the raccoon's ability to maintain an upright posture while I moved the live trap to different positions. A standard cream was applied on each eye to prevent desiccation of the cornea and conjunctiva. I recorded rectal temperature, respiration rate, and resting heart rate as soon as practical after immobilization. Additional rectal temperatures were taken at 10 -min intervals until handling procedures were completed. A numbered metal tag was attached to each ear. I also recorded weight and standard morphological measurements. Upon full recovery, raccoons were released at the capture site or relocated if captured as a nuisance animal in inhabited areas.

\section{Results and discussion}

Ten raccoons were immobilized during May and June, 1990-1991. Each raccoon was immobilized once with the exception of 1 raccoon which was immobilized again 28 days later to replace ear tags. Three raccoons were apparently underdosed with $22.2-25.2 \mathrm{mg} / \mathrm{kg} \mathrm{KH}(\bar{x}=23.4)$ and $4.4-5.0 \mathrm{mg} / \mathrm{kg} \mathrm{XH}(\bar{x}=4.7)$. Immobilization was achieved after each animal received an additional $6.0-10.2 \mathrm{mg} / \mathrm{kg} \mathrm{KH}(\bar{x}=$ $8.2)$ and $1.2-2.0 \mathrm{mg} / \mathrm{kg} \mathrm{XH}(\bar{x}=1.6)$.

Mean $( \pm \mathrm{SE})$ induction and recovery times $(n=8)$ were $3.4 \pm 0.5 \mathrm{~min}$ and 101.2 $\pm 27.8 \mathrm{~min}$, respectively (Table 1). Because of confounding results of multiple injections, data from the 3 raccoons that received 1 dose were not summarized. Induction and recovery times $(n=8)$ were similar to induction and walking times reported for captive raccoons immobilized with a $5: 1$ mixture of $\mathrm{KH} / \mathrm{XH}$ at approximately $25-50 \%$ of the total drug amount used in this study (Deresienski and Rupprecht 1989). Additionally, heart rate was almost identical to values reported by Deresienski and Rupprecht (1989) for captive raccoons. Mean resting body temperature decreased $1.3^{\circ} \mathrm{C}$ between 0 and 20 min post-recumbency.

Induction was characterized by slight nasal discharge and 2 instances of minor hypersalivation. Three individuals experienced minor twitching shortly before arousal. Typical early recovery behavior included ear twitching, fixed staring before eye blinking, and increased respiration. Control of the head returned first, 
Table 1. Dosages and physiological responses of raccoons immobilized with ketamine hydrochloride and xylazine hydrochloride. SE - standard error. ${ }^{a}$ standard deviation, ${ }^{b}$ rectal temperatures taken at 0,10 , and 20 min post-recumbency.

\begin{tabular}{llcccc}
\hline & $n$ & Mean & Median & SE & Range \\
\hline Ketamine hydrochloride $(\mathrm{mg} / \mathrm{kg})$ & 8 & 27.4 & 24.6 & $2.1^{\mathrm{a}}$ & $22.0-38.2$ \\
Xylazine hydrochloride $(\mathrm{mg} / \mathrm{kg})$ & 8 & 5.5 & 4.9 & $0.4^{\mathrm{a}}$ & $4.4-7.6$ \\
Induction time $(\mathrm{min})$ & 8 & 3.4 & 3.7 & 0.5 & $1.3-5.1$ \\
Arousal time (min) & 8 & 54.9 & 35.5 & 12.8 & $18.5-135.0$ \\
Standing time (min) & 8 & 76.1 & 47.5 & 18.1 & $23.4-160.0$ \\
Recovery time (min) & 8 & 101.2 & 59.4 & 27.8 & $34.4-272.2$ \\
Heart rate $(\mathrm{bpm})$ & 8 & 92 & 85 & 7.6 & $62-132$ \\
Respiration $(\mathrm{bpm})$ & 8 & 23 & 21 & 4.0 & $10-40$ \\
Temperature at $0 \min \left({ }^{\circ} \mathrm{C}\right)^{\mathrm{b}}$ & 8 & 37.9 & 38.0 & 0.35 & $36.0-39.0$ \\
Temperature at $10 \min \left({ }^{\circ} \mathrm{C}\right)^{\mathrm{b}}$ & 8 & 37.5 & 37.9 & 0.37 & $35.0-38.7$ \\
Temperature at $20 \min \left({ }^{\circ} \mathrm{C}\right)^{\mathrm{b}}$ & 6 & 36.6 & 36.5 & 0.41 & $35.0-38.0$ \\
\hline
\end{tabular}

followed by the front and hind legs. No episodes of spasms directly after induction or vomiting were observed, in contrast to Deresienski and Rupprecht (1989) who noted vomiting in 6 of 18 instances of raccoons immobilized with a lower dose of a $5: 1 \mathrm{KH} / \mathrm{XH}$ mixture. The $5: 1$ combination and dose range $(22.0-38.2 \mathrm{mg} / \mathrm{kg} \mathrm{KH}$ and $4.4-7.6 \mathrm{mg} / \mathrm{kg} \mathrm{XH}$ ) used in this study adequately immobilized wild raccoons for necessary handling and data collection procedures.

Acknowledgements: I thank J. D. Belant, J. E. Belant, M-K. W. Belant, C. M. Costello, C. L. Demers, M. S. Diesch, and R. W. Sage, Jr for assistance with field work. Partial material and logistical support was provided through the State University of New York College of Environmental Science and Forestry's Adirondack Ecological Center. Financial support was provided by the New York State Trappers Association, National Trappers Association, and Adirondack Wildlife Program funded by the New York State Legislature.

\section{References}

Aronson C. E. (ed) 1984. Veterinary pharmaceuticals and biologicals, 4th ed. Veterinary Medicine Publ. Co., Edwardsville, Kansas: 1-1041.

Belant J. L. 1991. Immobilization of fishers (Martes pennanti) with ketamine hydrochloride and xylazine hydrochloride. Journal of Wildlife Diseases 27: 328-330.

Belant J. L. 1992. Field immobilization of American martens and short-tailed weasels. Journal of Wildlife Diseases 28: 662-665.

Bigler W. J. and Hoff G. L. 1974. Anesthesia of raccoons with ketamine hydrochloride. Journal of Wildlife Management 38: 364-366.

Deresienski D. T. and Rupprecht C. E. 1989. Yohimbine reversal of ketamine-xylazine immobilization of raccoons (Procyon lotor). Journal of Wildlife Diseases 25: 169-174.

Docherty J. R. and Starke K. 1981. Postsynaptic alpha-adrenoceptor subtypes in rabbit blood vessels and rat anococcygeus muscle studied in vitro. Journal of Cardiovascular Pharmacology 3: 854-866. 
Endres K. M. 1989. Behavior and ecology of an island population of raccoons (Procyon lotor) within the Central Basin, Tennessee. M Sc thesis, Tennessee Technological University, Cookeville: 1-29.

Gregg D. A. and Olson L. D. 1975. The use of ketamine hydrochloride as an anesthetic for raccoons. Journal of Wildlife Diseases 11: 335-337.

Harthoorn A. M. 1976. The chemical capture of animals. Bailliere Tindall, London: 1-416.

Hsu W. H. 1985. Xylazine-pentobarbital anesthesia in dogs and its antagonism by yohimbine. American Journal of Veterinary Research 46: 852-855.

Keeler W. E. 1978. Some aspects of the natural history of the raccoon (Procyon lotor) in Cades Cove, the Great Smoky Mountains National Park. M Sc thesis, University of Tennessee, Knoxville: 1-81.

Klide A. M., Calderwood H. W. and Soma L. R. 1975. Cardiopulmonary effects of xylazine in dogs. American Journal of Veterinary Research 36: 931-935.

Mech L. D. 1965. Sodium pentobarbital as an anesthetic for raccoons. Journal of Mammalogy 46: 343-344.

Moore D. W. 1983. Density estimation and population biology of the raccoon (Procyon lotor) in western Tennessee. M Sc thesis, Memphis State University, Memphis, Tennessee: 1-62.

Ramsden R. O., Coppin P. F. and Johnston D. H. 1976. Clinical observations on the use of ketamine hydrochloride in wild carnivores. Journal of Wildlife Diseases 12: 221-225.

Seal U. S. and Erickson A. W. 1969. Immobilization of Carnivora and other mammals with phencyclidine and promazine. Federation Proceedings 28: 1410-1419.

Seal U. S., Erickson A. W. and Mayo J. G. 1970. Drug immobilisation of the Carnivora. International Zoo Yearbook 10: 157-170.

Seal U. S. and Kreeger T. J. 1987. Chemical immobilization of furbearers. [In: Wild furbearer management and conservation in North America. M. Novak, J. A. Baker, M. E. Obbard and B. Malloch, eds]. Ontario Trappers Association, North Bay, Ontario: 191-215.

Tabatabai F. R. 1988. Ecology of the raccoon (Procyon lotor) in Tennessee. Ph D thesis, Memphis State University, Memphis, Tennessee: 1-188.

Received 13 March 1995, accepted 16 August 1995. 